2014

\title{
Context-dependent patterns, determinants and demographic consequences of herbivory in an invasive species
}

Post-print/Accepted manuscript

Shekhar R. Biswas

Peter M. Kotanen

Dasvinder Kambo

Helene H. Wagner

Biswas, S.R., Kotanen, P.M., Kambo, D. et al. Biol Invasions (2015) 17: 165. doi:10.1007/s10530-014-0715-0

The final publication is available at Springer via http://dx.doi.org/10.1007/s10530-014-0715-0

\section{HOW TO CITE TSPACE ITEMS}

Always cite the published version, so the author(s) will receive recognition through services that track citation counts, e.g. Scopus. If you need to cite the page number of the TSpace version (original manuscript or accepted manuscript) because you cannot access the published version, then cite the TSpace version in addition to the published version using the permanent URI (handle) found on the record page. 
Biswas et al.: Herbivory in A. petiolata

1 Context-dependent patterns, determinants and demographic consequences of herbivory in

\section{2 an invasive species}

3

4 Shekhar R. Biswas ${ }^{1}$, Peter M. Kotanen, Dasvinder Kambo, Helene H. Wagner

5

6 Department of Ecology and Evolutionary Biology, University of Toronto, 3359 Mississauga

7 Road North, Mississauga, Ontario, Canada L5L1C6

8

9

10 Date of the manuscript draft: April 4, 2014

11 Manuscript word count (introduction to end of figure legends): 7240

12 Number of figures: 5

13 Number of Tables: 2

14 Number of supplementary materials: 3

15

\footnotetext{
${ }^{1}$ E-mail: shekhar.forest@gmailcom
} 


\section{Abstract}

Non-native invasive plants often lose many of their specialist herbivores in their invaded ranges, but new enemies may be recruited from the local generalist fauna, or from enemies themselves introduced to the same region. As a result, few invaders are free of herbivore damage; however, the incidence of this herbivory and its consequences for plant demography may depend on an array of biotic and abiotic factors. In Alliaria petiolata, a non-native invasive forb in Canada, we quantified the incidence of leaf herbivory, rosette survival and seed production along with conspecific plant density and environmental site conditions in wild populations in mesic forest understory and moist grasslands. We complemented the field survey by a laboratory experiment with Trichoplusia to test whether the palatability of leaf tissue of $A$. petiolata varies with plant life stage and habitat type. Incidence of herbivory was significantly higher in adults than in rosettes, and significantly higher in grasslands than in forest understory. The palatability experiment confirmed that leaves of adults were more palatable to a generalist herbivore than leaves of rosettes. Path analysis revealed negative plant density-dependent herbivory of adults in forest understory but positive density-dependent herbivory in grasslands. Incidence of herbivory in rosettes was positively associated with soil moisture in grasslands, but not in forest understory. Seed production was significantly positively associated with herbivory in adults and soil moisture, whereas rosette survival was significantly negatively associated with conspecific plant density. We conclude that the patterns, determinants and demographic consequences of herbivory in invasive Alliaria may strongly depend on a plant's life stage and plant density and may further be confounded by landscape heterogeneity.

Key Words: Alliaria petiolata; density-dependent herbivory; natural enemies; path analysis 


\section{Introduction}

Plant-herbivore interactions play a crucial role in structuring ecological populations and

41 communities (Harper 1977; Crawley 1989; Moran and Crone 2006). However, non-native plants

42 often lose many of their specialized enemies in invaded regions, potentially resulting in reduced

43 damage in their new environment (Elton 1958). While many empirical studies support this view

44 (Keane and Crawley 2002; Torchin and Mitchell 2004; Mitchell et al. 2006; Liu and Stiling

45 2006), numerous exceptions exist (see reviews by Colautti et al. 2004; Heger and Jeschke 2014).

46 One reason for these exceptions is that, even if invasive plants lose old enemies in new areas,

47 they may quickly acquire new ones from the local fauna (Levine et al. 2004; Hawkes 2007;

48 Hatcher and Dunn 2011, Dostal et al. 2013). Damage by these new herbivores may depend on an

49 array of biotic and abiotic factors, but these sources of variation are still poorly understood

50 (Dostal et al. 2013).

51 Environmental site conditions often govern the presence and abundance of plants and

52 herbivores (Scholwalter and Lowman 1999). High herbivory is expected in habitats where

53 environmental conditions are favourable for herbivores (Hawkes and Sullivan 2001; Dostal et al.

54 2013). As well, factors beyond environmental conditions may moderate herbivory, such as

55 density of the host plant (Parmesan 2000; Giffard et al. 2012). Host plants offer food or shelter

56 for herbivores, thus a reduced density of host plants may be less attractive to herbivores (Torres

57 1992) due to increased foraging costs or the deterring effects of co-occurring non-host plants or

58 bare ground (Risch 1980; Visser 1986; Scholwalter and Lowman 1999; Giffard et al. 2012). Per-

59 capita herbivory may thus increase with increasing plant density. Alternatively, increasing plant

60 density may reduce per-capita herbivory: if a fixed number of herbivores feeds on a large

61 number of plants, per-capita herbivory would be lower than if they feed on fewer plants. 
62 However, while plant density may affect herbivory directly, environmental conditions may

63 modulate herbivory directly as well as indirectly via plant density (Fig. 1).

Herbivory may further vary between life stages of a plant (Louda and Potvin 1995; Boege

65 and Marquis 2005; Boege et al. 2007; Barton and Koricheva 2010; Massad 2013). A plant

66 species may encounter higher herbivory in its juvenile stage than in its adult stage because the

67 tissue of juvenile plants contains less lignin (Lowman and Box 1983; Loney et al. 2006, Barton

68 and Koricheva 2010, Massad 2013) or because the acquisition or allocation of resources limit

69 juvenile investment in defense (Herms and Mattson 1992). On the other hand, selection pressure

70 by herbivores in the long run may lead to high levels of defense investment in juveniles (McKey

71 1974; Barton and Koricheva 2010), since a plant’s investment in chemical defense depends on

72 the functional value of a living tissue to the plant's life cycle (McCall and Fordyce 2010). The

73 dependence of herbivory on plant life stage may further vary with habitat type because a plant's

74 defense expression against herbivory may depend on environmental site conditions such as soil

75 moisture, light or site productivity (Lewis et al. 2006; Cipollini and Lieurance 2012). As well,

76 environmental cues may provide an indication about the risk of herbivory, allowing plants to

77 initiate appropriate defenses (see review by Frost et al. 2008).

Herbivory often affects plant demographic traits such as reproduction of adults or

79 survivorship of juveniles (Crawley 1989, Massad 2013), although herbivore tolerance can greatly

80 reduce these impacts (Rosenthal and Kotanen 1994; Strauss and Agrawal 1999; Bossdorf et al.

81 2004a; MacDonald and Kotanen 2010). In natural landscapes, plant density and environmental

82 conditions also modulate these demographic traits (Huntly 1991). Thus, observable plant

83 demographic traits are the combined outcome of direct and indirect effects of environmental

84 conditions, plant density and herbivory (Moran and Crone 2006; Fig. 1). Experimental 
85 investigation of these direct and indirect effects is challenging, as patterns observed in

86 experimental herbivory enclosures or simulated herbivory (e.g., clipping) may differ from actual

87 herbivory in wild populations (Baldwin 1990; Giffard et al. 2012). Hence, a survey of herbivory

88 in wild populations may reflect natural patterns, where the relative importance of direct and

89 indirect effects of different biotic and abiotic factors may be assessed through statistical

90 modeling such as path analysis (Shipley 2000).

$91 \quad$ Alliaria petiolata (M. Bieb.) Cavara and Grande (Brassicaceae) is a Eurasian native and

92 an invasive species in North America. This plant is a biennial forb with two distinct life stages:

93 first year rosette and second year adult (Cavers et al. 1979). It occurs in diverse habitats such as

94 forest understory, forest edges, grasslands, or roadsides verges; soil moisture and light are the

95 important variables affecting population growth and demographic parameters of this species

96 (Cavers et al. 1979; Nuzzo 2000; Meekins and McCarthy 2001). While A. petiolata encounters

97 damage from at least 69 different species of insects and seven species of fungi in Europe (Hinz

98 and Gerber 1998), it escapes from most in North America (Renwick et al. 2001; Lewis et al.

99 2006), and thus is often suggested as an example of enemy release. Still, previous studies suggest

100 A. petiolata in North America encounters herbivory from generalists in both adult and rosette life

101 stages (Lewis et al. 2006; Yates and Murphy 2008). Defense by A. petiolata against herbivory

102 may depend on local factors including environmental site conditions, types and density of local

103 populations of herbivores, connectivity of habitat and population age (Haribala and Renwick

104 2001; Lankau et al. 2009; Lewis et al. 2006). However, there is a lack of detailed research on

105 causes of variation in herbivory incidence among wild populations of invasive species like $A$.

106 petiolata. 
Here, we quantified the incidence of leaf herbivory, conspecific host plant density,

108 environmental site conditions (soil moisture and light) and two demographic traits (rosette

109 survival and adult fitness) in established wild populations of $A$. petiolata in mesic forest

110 understory and moist grasslands. We addressed the following questions: (i) Does the incidence of

111 herbivory vary with plant life stage and habitat type? (ii) Does the palatability of leaf tissue to a

112 generalist herbivore vary with plant life stage and habitat type? (iii) What are the direct and

113 indirect effects of environmental conditions and conspecific plant density on herbivory? (iv)

114 What are the direct and indirect effects of herbivory, environmental conditions and conspecific

115 plant density on juvenile survival and adult fitness? This knowledge would clarify the potential

116 dependency of herbivory and plant demography on biotic and abiotic factors.

118 Methods

119 Field sampling

120 We conducted this study in the Koffler Scientific Reserve (KSR) at Jokers Hill, King

121 City, Ontario, Canada, about $40 \mathrm{~km}$ north of Toronto $\left(44.0^{\circ} \mathrm{N}, 79.5^{\circ} \mathrm{W}, \sim 300 \mathrm{~m}\right.$ ASL $)$. In the

122 study area, A. petiolata occurs in several large established populations in forest understory,

123 grasslands and along nature trails; smaller patches and scattered individuals also occur

124 throughout this area. Naturalists working in the area suggest that these populations are at least 125 20-25 years old, while A. petiolata has occurred in the Toronto area since at least 1879 (Cavers 126 et al. 1979). Detailed maps of topography, vegetation and soil conditions in the study area are 127 available at http://ksr.utoronto.ca/.

128 In August 2009, we marked six A. petiolata patches-three in forest understory and three 129 in grasslands - and established transects of permanent sampling quadrats in each patch. Though 
130 the number of patches sampled was small, these sites are representative of the (as yet) limited

131 number of severely invaded sites at this location; in particular, grasslands represent open, moist

132 habitat (soil moisture range: 22.33 - 47.40\%), while the forest understory represents closed,

133 mesic habitat (8.30 - 29.70\%). Patches were separated from each other by a minimum of $75 \mathrm{~m}$.

134 A. petiolata patches within each of the two habitat types were comparable with respect to

135 topography and above-ground vegetation. For each patch $(N=6)$, we laid out four perpendicular

136 radial transects of contiguous $1 \mathrm{~m}^{2}$ quadrats extending from the center to the edge of an $A$.

137 petiolata patch. The number of $1 \mathrm{~m}^{2}$ quadrats per transect varied from $12-25$ in forest understory

138 and 7 - 14 in grasslands. In total we marked 196 permanent quadrats from mesic forest

139 understory and 109 quadrats from moist grasslands.

140 In June 2010, we counted the number of adults $A_{\text {June }}$ and rosettes $R_{\text {June }}$ in each marked

141 quadrat $(N=305)$, and quantified the incidence of leaf herbivory (binary; per leaf), separately

142 for adults and rosettes. We did not identify herbivores; however, snails and slugs (class

143 Gastropoda), a stem and leaf mining weevil (Ceutorhynchus erysimi Fabr.), diamondback moth

144 (Plutella xylostella), meadow spittlebug (Philaenus spumarius), and caterpillars (Lepidoptera:

145 Pieridae) are known herbivores of A. petiolata in North America (Evans and Landis 2007; Yates

146 and Murphy 2008). Interestingly, most of these herbivores (including the gastropods, Plutella,

147 Ceutorhynchus, Philaenus, and some Pieridae) are European in origin. We suspect gastropods

148 were the most important herbivores at our site.

149 In each quadrat, we randomly selected three rosettes and three adults and counted the

150 total number of leaves and the number of leaves with visible signs of herbivory, e.g., leaf holes,

151 scars, chewing etc. Presence of at least three holes/scars/chewing signs on a leaf ( 3\% of total

152 leaf area) was the minimum level of damage we considered to count a leaf damaged by 
153 herbivores. Individual rosettes or adults of A. petiolata comprise relatively few leaves (typically,

1542 - 4 leaves in a rosette and 7 - 12 leaves in a single-stemmed adult); thus, we estimated the 155 proportion of leaves with herbivory at the quadrat level $H_{i}$ by applying a correction for small 156 samples (De Veaux et al. 2012), separately for adults and rosettes. quadrat.

Soil moisture content may affect both plant growth and moisture-sensitive herbivores

161 such as gastropods. We measured soil moisture content and light for each quadrat $(N=305)$.

162 Using a TDR probe, we took three measurements of soil moisture (percentage of soil volume)

163 within each quadrat and averaged them to represent a quadrat. All soil moisture measurements

164 were taken within a period of three days without any rainfall event for seven days prior to the 165 sampling days. For light, we took a canopy image at breast height (using a Digital Plant Canopy 166 Imager CI-110) in each quadrat and analyzed the image for leaf area index (Jonckheere et al. 167 2004). This approach uses canopy openness as a proxy for light availability, but should be less 168 sensitive to sun angle, time of day, or cloudiness than direct measurements of light intensity. In October 2010, we re-counted the number of rosettes in each quadrat $\left(R_{O c t}\right)$. Then, we 170 computed per-capita rosette survival as, $R_{O c t} / R_{\text {June }}$. For adult, we quantified the number of seeds 171 per adult plant, which we measured at the same time as the herbivory measurement (June). We 172 counted the number of pods $\left(n_{\text {pods }}\right)$ for each of the three randomly selected adults in each quadrat 173 and opened three randomly selected pods (if a plant had only two pods, we opened two) from 174 each plant to count the number of seeds per pod $\left(n_{\text {seed }}\right)$. By multiplying the average number of 
175 seeds per pod and the average number of pods per plant, we quantified quadrat-level seed

176 production per adult plant $\left(n_{\text {pods }} \times n_{\text {seed }}\right)$.

178 Leaf palatability experiment

179 To complement the survey of natural populations, we tested in a laboratory setting

180 whether the palatability of leaf tissue of $A$. petiolata varies with plant life stage and habitat type.

181 We conducted a factorial experiment using Trichoplusia ni Hübner (Noctuidae). Trichoplusia is

182 found throughout North America and considered as a major pest of crucifer crops; it is

183 commonly used as a generalist herbivore in plant-herbivory studies (e.g., Cipollini 2002; Scott et

184 al. 2010). We obtained Trichoplusia eggs from the Canadian Forest Service, Great Lakes

185 Forestry Centre, Sault Ste. Marie, Canada (http://cfs.nrcan.gc.ca/pages/320).

In July 2012, we collected leaves that were comparable in age and size from all three

187 forest understory and three grassland sites. Leaves of adults and rosettes were collected from

188 separate individuals. We cut each leaf to a disk shape, so that all experimental leaves had the

189 same leaf area $\left(10.2 \mathrm{~cm}^{2}\right)$, and recorded the weight of each leaf $\left(W_{i}\right)$. For each of the four

190 treatments (combination of life stage: adult vs. rosette and habitat: forest understory vs.

191 grasslands), ten replicate leaves were treated with single Trichoplusia larvae (mean \pm sd weight:

$1920.0146 \pm 0.0044 \mathrm{~g}$ ) and ten used as control (without herbivore), for a total of 40 treated leaves and

19340 control leaves. We placed each leaf in a petri dish, covered them with Parafilm (Pechiney

194 Plastics Packaging) to prevent desiccation and placed them on a laboratory table where regular

195 room temperature $\left(20^{\circ} \mathrm{C}\right)$ and normal day-night cycles (approximately 14 hours day length in 196 July) were maintained. 
After a week, we terminated the experiment and re-weighted each leaf $\left(W_{f}\right)$ using a digital

198

199

200

201

202

203

204

205

206

207

208

209

210

211

212

213

214

215

216

217

218

219

scale. For each leaf, weight loss per unit biomass $\left(W_{l}\right)$ was defined as, $\left(W_{f}-W_{i}\right) / W_{i}$. In herbivoretreated leaves, tissue loss through herbivory and loss of leaf moisture through evaporation were the two possible reasons for weight loss, while in control leaves, weight loss was only due to loss of leaf moisture. Quantifying weight loss is a common practice in herbivory studies; although we cannot rule out the confounding effect of differential evaporation rates between intact control and damaged leaves, differences in area removed were visually obvious and agreed qualitatively with weight estimates (see below).

\section{Statistical analyses}

Survey data: To test whether the incidence of herbivory varies with plant life stage and habitat type, we used the function 'errorsarlm’ in R library “spdep” (Bivand et al. 20012) to conduct a mixed-model analysis of variance with a spatially correlated error term to account for spatial structure (coefficient of the spatial error term, $\lambda: 0.41 ; P<0.01$ ). We defined the model as: incidence of leaf herbivory $\sim \mu$ + life-stage (fixed) + habitat-type (fixed) + patch (random) + habitat-type $\mathrm{x}$ life-stage $+\lambda \mathbf{W}+$ independent error $(\varepsilon)$, where $\mu$ is the intercept, and $\lambda$ is the coefficient of the spatial error term, which is defined by the spatial weight matrix $\mathbf{W}$ (adjacent quadrats were considered as neighbors following rooks connection; binary weight). To improve residual distributions, herbivory incidence data was transformed to log odds (logit), plant density to square roots, and soil moisture and light to natural logarithm. The proportion of variance explained by the model (pseudo- $R^{2}$ ) was calculated as the squared correlation of the fitted values predicted from all non-spatial predictors in the model (i.e., without spatial error term) and the original transformed variable. 
221 fitted a series of path models (Shipley 2000), separately for each of the two habitat types and for

222 adult and rosette life stages. Path analysis is similar to the linear regression model (Mysterud et

223 al. 2008), so that the assumption of independent and normal distribution of residuals applies to

224 path analysis. In our data from transect sampling, there was significant residual autocorrelation

225 (see Online Resource 1 for the spatial structure and distribution of variables). We modified path

226 analysis to include spatial error terms in each of the regression models required to fit path

227 coefficients (Olbatuyi 2006). The standardized path coefficients were estimated from a series of

228 multiple spatial regressions with correlated error terms, using type III sum of square. The

229 regression models were defined as follows (equations 1-6):

230

231

232

233

234

235

$$
\mathrm{D}_{\mathrm{r}} \sim p_{1} \mathrm{~L}+p_{2} \mathrm{M}+\lambda \mathrm{W}+\varepsilon
$$

$$
\mathrm{H}_{\mathrm{r}} \sim p_{3} \mathrm{D}+p_{4} \mathrm{~L}+p_{5} \mathrm{M}+\lambda \mathrm{W}+\varepsilon
$$

$$
\mathrm{S}_{\mathrm{r}} \sim p_{6} \mathrm{D}+p_{7} \mathrm{H}_{\mathrm{r}}+p_{8} \mathrm{~L}+p_{9} \mathrm{M}+\lambda \mathrm{W}+\varepsilon
$$$$
\mathrm{D}_{\mathrm{a}} \sim p_{1} \mathrm{~L}+p_{2} \mathrm{M}+\lambda \mathrm{W}+\varepsilon
$$

$$
\mathrm{H}_{\mathrm{a}} \sim p_{3} \mathrm{D}+p_{4} \mathrm{~L}+p_{5} \mathrm{M}+\lambda \mathrm{W}+\varepsilon
$$

$$
\mathrm{F}_{\mathrm{a}} \sim p_{6} \mathrm{D}+p_{7} \mathrm{H}_{\mathrm{a}}+p_{8} \mathrm{~L}+p_{9} \mathrm{M}+\lambda \mathrm{W}+\varepsilon
$$

where $D_{r}=$ rosette density , $D_{a}=$ adult density, $D=$ conspecific density (adult + rosette), $L=$

237 light, $M=$ soil moisture, $H_{a}=$ incidence of adult herbivory, $H_{r}=$ incidence of rosette herbivory,

$238 S_{r}=$ per-capita rosette survival, $F_{a}=$ per-capita adult seed production, $p=$ standardized path

239 coefficients, $\lambda=$ is the coefficient of the spatial error term, which is defined by the spatial weight

240 matrix $W$ where adjacent quadrats were considered as neighbours (binary weights), and $\varepsilon=$

241 independent error term for corresponding regression. To improve residual distribution and model

242 fit, conspecific plant density data was transformed to square roots, light and soil moisture to 
243 natural logarithm, incidence of herbivory and per-capita rosette survival to logit, and per-capita

244 adult seed production to natural logarithm. To avoid computational problems with survival data,

245 proportions of 1 and 0 were replaced by 0.99 and 0.01 , respectively. Transformed variables were

246 standardized to mean of zero and standard deviation of one; therefore, we did not fit any

247 intercept and the slope coefficients $\left(p_{1-9}\right)$ represent standardized path coefficients. Residual

248 analyses revealed that transformations were successful in normalizing the non-spatial residuals

249 (Online Resource 2).

250 The standardized path coefficients $\left(p_{1-9}\right)$ represent the direct effects. Indirect effects were 251 quantified as follows: (i) effect of soil moisture on herbivory incidence $=p_{2} p_{3}$, (ii) effect of soil

252 moisture on rosette survival/adult seed production $=p_{2} p_{6}+p_{5} p_{7}$, (iii) effect of light on herbivory

253 incidence $=p_{1} p_{3}$, (iv) effect of light on rosette survival/adult seed production $=p_{1} p_{6+} p_{4} p_{7}$, and

$254(v)$ effect of conspecific plant density on rosette survival/adult seed production $=p_{3} p_{7}$. All

255 statistical analyses were conducted in R 2.14.2 (R Development Core Team 2011).

256 Experimental data: To test whether the palatability of leaf tissues varies with plant life

257 stage and habitat type, we ran a three-way fixed-effects factorial ANOVA (type III sum of

258 squares) where $W_{i}$ was the response variable, and plant life stage (Pls), habitat type (Habt) and

259 herbivory treatment (Herb) were the predictors (equation 7). The residuals were slightly skewed

260 (kurtosis: 1.97) but transformation did not improve residual distribution; we proceeded with 261 untransformed data. 
Biswas et al.: Herbivory in A. petiolata

\section{Results}

264 Incidence of herbivory (survey data)

265 Incidence of herbivory in natural populations varied strongly with plant life stage $(P$

$266<0.01$; see Online Resource 3$)$ and habitat type $(P<0.01)$, but the interaction between plant life

267 stage and habitat type was not significant $(P=0.68)$. Overall, incidence of herbivory was

268 significantly higher in adults than in rosettes and higher in grasslands than in forest understory

269 (Fig. 2). In rosettes, the mean \pm sd proportion of per-capita herbivory incidence was $0.26 \pm 0.11$

270 (range: $0.12-0.88)$ in forest understory and $0.59 \pm 0.20(0.12-0.87)$ in grasslands. In adults, the

271 mean \pm sd proportion of per-capita herbivory incidence was $0.43 \pm 0.17(0.04-0.88)$ in forest

272 understory and $0.68 \pm 0.22(0.50-0.97)$ in grasslands.

273

274 Effects of environmental factors and host plant density on herbivory

275 For rosettes, there was a significant positive association between soil moisture and

276 herbivory incidence in moist grasslands $(P<0.01$, Fig. 3); the effect was not significant in mesic

277 forest understory (Table 1). In adults, incidence of herbivory was significantly negatively

278 associated with conspecific plant density in forest understory $(P=0.04)$ but positively associated

279 in grasslands (Fig. 3). We failed to detect any significant effect of light on herbivory. The effects

280 of environmental conditions (moisture and light) on incidence of herbivory were mostly direct

281 (Table 1).

282

283 Effects of herbivory, environmental factors and plant density on plant demography

284 The mean \pm sd seeds per adult was 265.2 \pm 276.45 (range: $6.9-2224$ ) in forest understory 285 and 855.1 \pm 328.76 (127.9 - 1033) in grasslands. The association between incidence of herbivory 
286

287

288

289

290

291

292

293

294

295

296

297

298

299

300

301

302

303

304

305

306

307

308

and adult seed production was significantly positive in both forest understory and grasslands ( $P$ $<0.01$; Fig. 3). The mean \pm sd proportion of rosette survival per quadrat was $0.28 \pm 0.17(0.01-$ $0.88)$ in forest understory and $0.47 \pm 0.23(0.01-0.85)$ in grasslands. The association between incidence of herbivory and rosette survival was not statistically significant in either habitat (Table 1). Conspecific plant density had significant negative effects on rosette survival in forest understory $(P=0.03)$ and significant positive effects on adult seed production in grasslands $(P$ $<0.01)$. Soil moisture showed significant positive effects on rosette survival in grasslands $(P<$ 0.01) and on adult seed production in forest understory (Fig. 3, Table 1). Light had a significant positive effect on rosette survival in grasslands $(P<0.01)$. The effects of environmental conditions, conspecific plant density and incidence of herbivory on adult seed production and rosette survival were mostly direct. Only indirect effects of soil moisture and plant density on adult seed production were statistically significant (Fig 3, Table 1).

\section{Palatability of leaf tissue (experiment)}

Leaves showed obvious signs of herbivory (Fig. 4), and the loss of weight per unit leaf biomass was significantly higher in herbivore-treated leaves than in control leaves $(P<0.001$;

Table 2), indicating that leaf tissue was consumed by Trichoplusia. In both forest understory and grasslands, the weight loss was significantly lower in leaves of rosettes than adults $(P<0.001$;

Fig. 5). Though leaves from grasslands lost less weight than leaves from forest understory, after accounting for the marginal effects of life stage and habitat type, herbivory effects depended on the life stage, but not on habitat type, and the three-way interaction was not significant (Table 2). This means that leaf palatability varied with plant life stage: rosette leaves were less palatable than adult leaves. In fact, while Trichoplusia fed on adult leaves to a variable degree, they did 
309 not feed on rosette leaves at all (Fig. 4): weight loss in rosette leaves was due solely to loss of

310 leaf moisture through evaporation, as for the controls.

\section{Discussion}

313 Patterns of herbivory

314 Palatability of plant tissue is a key determinant of herbivory. Our laboratory experiment

315 showed that rosette leaves were much less palatable to a generalist herbivore than adult leaves

316 (Figs 4 and 5). Our result of lower juvenile than adult herbivory is unexpected because adult

317 leaves often experience less herbivory due to higher lignin content, at least in the case of

318 mammalian herbivores (Loney et al. 2006, Barton and Koricheva 2010); as well, in Europe,

319 rosettes of A. petiolata are heavily attacked by the weevil Ceutorhynchus scrobicollis (Davis et

320 al. 2006). This may explain the findings of higher herbivory in adults than rosettes in the field

321 study (Fig. 2), where generalists are likely to be the herbivores most commonly encountered by

322 A. petiolata. While we did not examine leaf chemistry, rosette leaves may contain higher

323 concentrations of herbivore-repellent toxic allelochemicals—such as glucosinolates and apigenin

324 flavonoids—-than adult leaves (Haribala and Renwick 2001). Adult plants must allocate finite

325 resources among growth, reproduction, persistence and defense, so that defensive and

326 reproductive allocations may compete (Bazzaz et al. 1987). In contrast, a rosette does not

327 allocate resources to reproduction and it may thus invest more in herbivory defense by producing

328 more allelochemicals, so that rosettes would experience less herbivory than adults. As well,

329 rosettes may represent an especially important life-history stage, as suggested by demographic

330 elasticity analyses (Davis et al. 2006; Evans et al. 2012); in contrast, once an adult has begun to 
331 set seed, there may be little or no selection pressure for further foliar defense in a biennial

332 species.

333 The incidence of herbivory was higher in grasslands than forest understory (Fig 2).

334 Environmental site conditions (e.g., canopy openness, dense ground-level vegetation or lack of 335 bare ground, and especially moisture) in grasslands may be more conducive to gastropods than 336 forest understory (moisture range: $22.33-47.40 \%$ in grasslands and $8.30-29.70 \%$ in forest

337 understory). Thus, abundance of generalist herbivores may be higher in grasslands, which would 338 explain the incidence of higher herbivory in grasslands than in forest understory.

339 Previous studies on A. petiolata herbivory did not distinguish incidence of herbivory in 340 different habitat types, and methodological details vary between studies. We quantified incidence 341 of herbivory as a binary variable based on a cut-off of approx. $3 \%$ of total leaf area, assessed by 342 the presence of 2 - 3 holes, spots or signs of herbivory per leaf. Based on these data, the overall 343 incidence of herbivory observed in this study is within the range of findings from previous 344 studies. Riper et al. (2010) found herbivory removed an average of $2 \%$ of leaf area (range of 345 means: 1.5 - 3\%) in 12 A. petiolata populations in Minnesota, USA. Evans and Landis (2007) 346 found an average leaf area removal of 2.3\% [range: $0.6-9.8 \%$ ] in spring and 4.5\% [range: 1.8 $3476.7 \%$ in fall in $88.2 \%$ of their 1280 sampled quadrats in 8 A. petiolata population in Michigan, 348 USA. In contrast, in native European populations (Hungary), Lewis et al. (2006) found that 349 herbivory removed $>10 \%$ leaf area. Collectively, these studies and ours suggest enemy release 350 has occurred in North America. 


\section{Determinants of herbivory}

A variety of biotic and abiotic factors may modulate herbivory in natural landscapes; we focused on conspecific plant density, soil moisture and light. In adults, we found positive plantdensity dependence of herbivory in grasslands but significantly negative plant-density dependence of herbivory in forest understory (Fig. 3). In rosettes, there was no statistically significant association between plant density and herbivory incidence. Herbivores may be more abundant in densely-vegetated grasslands than in sparsely vegetated forest understory, which could explain the observed reversal of the sign of density dependence of herbivory from positive in moist grassland to negative in mesic forest understory. Similarly, density-dependent herbivory might be less pronounced for rosettes simply because they are avoided by herbivores. This could be verified experimentally in future studies by quantifying intensity of herbivory along with densities of host plants and herbivores.

Regarding abiotic effects, in moist grasslands, we found significant positive effects of soil moisture on herbivory incidence in rosettes; soil moisture and canopy openness likely are conducive to some herbivores such as gastropods (slugs) or meadow spittlebugs. However, like Lewis et al (2006), we did not detect any significant effect of light on the incidence of herbivory (Table 1). We suspect that spatial and temporal heterogeneity may have masked any potential light effects on herbivory incidence; for instance, foliage may produce small-scale heterogeneity in light intensity not captured by our canopy measurements, while our snapshot measurements ignored temporal and seasonal variation in sun angle. With the caveat that our environmental variables are only snapshot measurements, we suggest that both environmental site conditions and host plant density are important determinants of herbivory incidence, but their effect may 
376 further depend on plant life stage and abundance of herbivores (Scholwalter and Lowman 1999;

377 Lewis et al. 2006).

379 Demographic consequences of herbivory

While herbivory is usually damaging to plants, the overall demographic consequences of

381 herbivory may be positive, negative or neutral (Huntly 1991). In rosettes, herbivory effects were

382 neutral -i.e., there was no statistically significant effect of incidence of herbivory on rosette

383 survival (Table 1). Although the observed incidence of herbivory (binary) was high, the actual

384 tissue removal may be too low to affect the plant (Evans and Landis 2007; Riper et al. 2010). In

385 adults however, the association between incidence of herbivory and adult fitness (seed

386 production) was significantly positive (Fig. 3). Due to the concurrent sampling of herbivory

387 incidence and adult fitness we cannot establish whether the observed high adult fitness was due

388 to high herbivory incidence or whether high herbivory incidence was due to plants of high

389 quality (Price 1991). For instance, larger plants may be more attractive to herbivores, so that

390 herbivores accumulated on these plants, which already have set seed and thus have less herbivore

391 defense. However, field observations suggested that in grasslands, where herbivory incidence

392 was high, plants generally had multiple shoots, which was likely induced by herbivore damage to

393 apical shoots in the early growing season (Bossdorf et al. 2004a). These findings are consistent

394 with Evans and Landis (2007) and Bossdorf et al. (2004a). Evans and Landis (2007), in a four-

395 year field-level demographic monitoring in A. petiolata, reported significant positive association

396 between the incidence of herbivory and adult fecundity. Bossdorf et al. (2004a) experimentally

397 showed that $A$. petiolata recovered greatly from leaf damage (after 75\% damage to the leaf area, 
398 regrowth was almost unaffected) and plants that had experienced stem damage were more 399 branched than undamaged plants.

401 consequences of herbivory. We found two significant indirect effects in adults: moisture effects

402 on adult seed production through plant density and herbivory in mesic forest understory, and

403 plant density effects on adult seed production through herbivory in moist grasslands; both

404 indirect effects amplified the effects of herbivory (Table 1). From the low pseudo- $R^{2}$ values

405 (range $<1$ to 30\%; see Fig. 3) in the path analyses we suspect that possible other indirect effects

406 were masked by unmeasured biotic and/or abiotic factors. Adaptations of $A$. petiolata to diverse

407 environmental conditions (Cavers et al. 1979; Nuzzo 2000; Meekins and McCarthy 2001) in

408 terms of variable demographic parameters (Evans et al. 2012), competitive ability (Meekins and 409 McCarthy 2002; Bossdorf et al. 2004b) or enemy defense (Haribala and Renwick 2001; Lewis et 410 al. 2006; Lankau et al. 2009) may contribute to such variability. Nonetheless, by combining the

411 results from both rosette and adult life stages over two different habitats, it seems that invasive $A$.

412 petiolata may be very tolerant to herbivory damage (Bossdorf et al. 2004a; Haribala and

413 Renwick 2001).

\section{Conclusions}

416 We suggest that patterns, determinants and demographic consequences of herbivory for

417 invasive plants are highly context-dependent, especially in heterogeneous natural landscapes

418 (Giffard et al. 2012). These results indicate that even for a highly invasive species such as

419 Alliaria, which apparently has escaped many of its native-range herbivores, enemy release (as

420 identified by herbivory damage) may be inconsistent; conversely, high tolerance may reduce the 
421 importance of any damage which does occur. Our striking finding of life stage-dependent

422 herbivory (Boege and Marquis 2005, Massad 2013), which is possibly related to a defense-

423 fitness trade off, suggests that A. petiolata may employ its defense strategies judiciously (McKey

424 1974; Bazzaz et al. 1987; McCall and Fordyce 2010). This also implies that there may be a

425 dependency of the effect of enemy release on the plant's ontogenetic stage (Massad 2013).

426 Investigation on the generality of this strategy in other biennial or perennial invasive species may

427 help understand ecological strategies of a successful invader.

\section{Acknowledgements}

The study was supported by NSERC Discovery Grants to PMK and HHW. We thank

431 Zangeetha Perinathan and Adrian DiFederico for assisting in the field survey, and Marie-Josée

432 Fortin, Benjamin Gilbert and Mark Vellend for their constructive comments on earlier versions

433 of this manuscript. All of the experiments conducted in this study comply with the current laws

434 of Canada. This is a publication of Koffler Scientific Reserve at Jokers Hill.

\section{References}

437 Baldwin IT (1990) Herbivory simulation in ecological research. TREE 5:91-93

438 Barton KE, Koricheva J (2010) The ontogeny of plant defense and herbivory: characterizing 439 general patterns using meta-analysis. The American Naturalist 175:481-493

440 Bazzaz FA, Chiarielo NR, Coley PD, Pitelka LF (1987) Allocating resources to reproduction and 441 defense. BioScience 37:58-67

442 Bivand R, Altman M, Anselin L, et al (2012) spdep: Spatial dependence: weighting schemes, $443 \quad$ statistics and models. R package version 0.5-46/r430 
Biswas et al.: Herbivory in A. petiolata

444 Boege K, Marquis RJ (2005) Facing herbivory as you grow up: the ontogeny of resistance in 445 plants. Trends in Ecology and Evolution 20: 441-448.

446 Boege K, Dirzo R, Siemens D, Brown P (2007) Ontogenic switches from plant resistance to 447 tolerance: minimizing costs with age? Ecology Letters 10: 177-187.

448 Bossdorf O, Schroder S, Prati D, Auge H (2004a) Palatability and tolerance to simulated 449 herbivory in native and introduced populations of Alliaria petiolata (Brassicaceae).

$450 \quad$ American Journal of Botany 91:856-862

451 Bossdorf O, Prati D, Auge H, Schmid B (2004b) Reduced competitive ability in an invasive $452 \quad$ plant. Ecology Letters 7:346-353

453 Cavers P, Heagy M, Kokron R (1979) The biology of Canadian weeds. 35. Alliaria petiolata (M.

454 Bieb.) Cavara and Grande. Canadian Journal of Plant Science 59:217-229.

455 Cipollini DF (2002) Variation in the expression of chemical defenses in Alliaria petiolata in the 456 field and common garden. American Journal of Botany 89: 1422-1430

457 Cipollini D, Lieurance DM (2012) Expression and costs of induced defense traits in Alliaria 458 petiolata, a widespread invasive plant. Basic and Applied Ecology 5:432-440

459 Colautti RI, Riccardi A, Grigorovich IA, MacIsaac HJ (2004) Is invasion success explained by 460 the enemy release hypothesis? Ecology Letters 7:721-733

461 Crawley MJ (1989) Insect herbivores and plant population dynamics. Annual Review of $462 \quad$ Entomology 34:531-564

463 Davis AS, Landis DA, Nuzzo V, Blossey B, Gerber E, Hinz HL (2006) Demographic models 464 inform selection of biocontrol agents for garlic mustard (Alliaria petiolata). Ecological $465 \quad$ Applications 16:2399-2410

466 De Veaux RD, Velleman PF, Bock DE (2012) Stats: Data and Models. Pearson 
Dostal P, Allan E, Dawson W, van Kleunen M, Bartish I, Fischer M (2013) Enemy damage of exotic plant species is similar to that of natives and increases with productivity. Journal of Ecology 101: 388-399

Elton CS (1958) The Ecology of Invasions by Plants and Animals. London: Methuen and Co

Evans J, Landis DA (2007) Pre-releasing monitoring of Alliaria petiolata (garlic mustard) invasions and the impacts of extant natural enemies in southern Michigan forests. Biological Control 42:300-307

Evans JA, Davis AS, Raghu R, Ragavendran A, Landis DA, Schemske DW (2012) The importance of space, time, and stochasticity to the demography and management of Alliaria petiolata. Ecological Applications 22:1497-1511

Frost JC, Mescher MC, Carlson JE, De Moraes CM (2008) Plant defense priming against herbivores: getting ready for a different battle. Plant Physiology 146: 818-824

Giffard B, Jactel H, Corcket E, Barbaro L (2012) Influence of surrounding vegetation on insect herbivory: a matter of spatial scale and herbivore specialisation. Basic and Applied Ecology $13: 458-465$

Haribal M, Renwick JAA (2001) Seasonal and population variation in flavonoid and alliarinoside content of Alliaria petiolata. Journal of Chemical Ecology 27:1585-1594

Harper JL (1977) Population Biology of Plants. Academic Press, New York, USA

Hatcher MJ, Dunn AM (2011) Parasites in Ecological Communities: From Interactions to

Ecosystems. Ca,mbridge University Press, Cambridge, UK

Hawkes CV (2007) Are invaders moving targets? The generality and persistence of advantages

in size, reproduction, and enemy release in invasive plant species with time since

$$
\text { introduction. American Naturalist 170:832-43 }
$$


Hawkes CV, Sullivan JJ (2001) The impact of herbivory on plants in different resource

491 conditions: a meta-analysis. Ecology 82:2045-2058

492 Heger T, Jeschke JM (2014) The enemy release hypothesis as a hierarchy of hypotheses. Oikos

$493 \quad$ Doi: 10.1111/j.1600-0706.2013.01263.x

494 Herms DA, Mattson WJ (1992) The dilemma of plants: to grow or defend. Quarterly Review of

$495 \quad$ Biology 67:283-335

496 Hinz HL, Gerber E (1998) Investigations on potential biological control agents of garlic mustard, 497 Alliaria petiolata (Bieb.) Cavara and Grande, Annual Report 1998. CABI Bioscience Centre $498 \quad$ Switzerland, Delémont, Switzerland

499 Huntly N (1919) Herbivores and the dynamics of communities and ecosystems. Annual Review $500 \quad$ of Ecology, Evolution and Systematics 22:477-503

501 Jonckheere I, Fleck S, Nackaerts K, Muys B, Coppin P, Weiss M, Baret F (2004) Review of 502 methods for in situ leaf area index determination: Part I. Theories, sensors and hemispherical 503 photography. Agric For Meteorol 121:19-35

504 Keane RM, Crawley MJ (2002) Exotic plant invasions and the enemy release hypothesis. Trends $505 \quad$ in Ecology and Evolution 17:164-170

506 Lankau RA, Nuzzo V, Spyreas G, Davis AS (2009) Evolutionary limits ameliorate the negative 507 impact of an invasive plant. Proceedings of the National Academy of Sciences USA 508 $106: 15362-15367$

509 Levine JM, Adler PB, Yelenik SG (2004) A meta-analysis of biotic resistance to exotic plant $510 \quad$ invasions. Ecology Letters 7:975-989 
Biswas et al.: Herbivory in A. petiolata

511 Lewis KC, Bazzaz FA, Liao Q (2006) Geographic patterns of herbivory and resource allocation

512 to defense, growth and reproduction in an invasive biennial, Alliaria petiolata. Oecologia

$513 \quad 148: 384-395$

514 Liu H, Stiling P (2006) Testing the enemy release hypothesis: a review and meta-analysis.

$515 \quad$ Biological Invasions 8: 1535-1545

516 Loney PE, McArthur C, Potts BM, Jordan GJ (2006) How does ontogeny in a Eucalyptus species

517 affect patterns of herbivory by Brushtail Possums? Functional Ecology 20: 982-988

518 Louda SM, Potvin MA (1995) Effect of inflorescence-feeding insects on the demography and

519 lifetime fitness of a native plant. Ecology 76:229-245

520 Lowman MD, Box JH (1983) Variation in leaf toughness and phenolic content among five

521 species of Australia rain forest trees. Australian Journal of Ecology 8:17-25

522 MacDonald AAM, Kotanen PM (2010) Leaf damage has weak effects on growth and fecundity

523 of common ragweed (Ambrosia artemisiifolia). Botany 88:158-164

524 Massad TJ (2013) Ontogenic differences of herbivory on woody and herbaceous plants: a meta-

525 analysis demonstrating unique effects of herbivory on the young and the old, the slow and the

526 fast. Oecologia 172:1-10

527 McCall AC, Fordyce JA (2010) Can optimal defense theory be used to predict the distribution of

528 plant chemical defenses? Journal of Ecology 98:985-992

529 McKey D (1974) Adaptive patterns in alkaloid physiology. American Naturalist 108:305-320

530 Meekins JF, McCarthy BC (2001) Effect of environmental variation on the invasive success of a

$531 \quad$ nonindigenous forest herb. Ecological Applications 11:1336-1348 
Biswas et al.: Herbivory in A. petiolata

532 Meekins JF, McCarthy BC (2002) Effect of population density on the demography of an invasive

533 plant (Alliaria petiolata, Brassicaceae) population in a southeastern Ohio forest. American

$534 \quad$ Midland Naturalist 147:256-278

535 Mitchell CE, Agrawal AA, Bever JD, Gilbert GS, Hufbauer RA, Klironomos JN, Maron JL, 536 Morris WF, Parker IM, Power AG, Seabloom EW, Torchin ME, Vázquez DP (2006) Biotic

537 interactions and plant invasions. Ecology Letters 9:726-740

538 Moran JL, Crone E (2006) Herbivory: effects on plant abundance, distribution and population

539 growth. Proceedings of the Royal Society B 273:2575-2584

540 Mysterud A, Yoccoz NG, Langvatn R, Pettorelli N, Stenseth NC (2008) Hierarchical path

541 analysis of deer responses to direct and indirect effects of climate in northern forest.

542 Philosophical Transections of the Royal Society B 363:2359-2368

543 Nuzzo VA (2000) Element Stewardship Abstract for Alliaria petiolata (Alliaria officinalis)

544 Garlic Mustard. The Nature Conservancy, Arlington, VA.

545 Olobatuyi ME (2006) A user’s guide to path analysis. University Press of America Inc, Maryland

546 Parmesan C (2000) Unexpected density-dependent effects of herbivory in a wild population of

547 the annual Collinsia torreyi. Journal of Ecology 88:392-400

548 Price PW (1991) The plant vigor hypothesis and herbivore attack. Oikos 62:244-251

549 R Development Core Team (2011) R: A language and environment for statistical computing.

$550 \quad$ Viena: R Foundation for Statistical Computing.

551 Renwick JAA, Zhang W, Haribal M, Attygalle AB, Lopez KD (2001) Dual chemical barriers

552 protect a plant against different larval stages of an insect. Journal of Chemical Ecology

$553 \quad 27: 1575-1583$ 
Biswas et al.: Herbivory in A. petiolata

554 Riper LCV, Becker RL, Skinner LC (2010) Population biology of garlic mustard (Alliaria

555 petiolata) in Minnesota Hardwood forests. Invasive Plant Science and Management 3:48-59

556 Risch S (1980) The population dynamics of several herbivorous beetles in a tropical

557 agroecosystem: the effect of intercropping corn, beans and squash in Costa Rica. Journal of

$558 \quad$ Applied Ecology 17:593-612

559 Rosenthal JP, Kotanen PM (1994) Terrestrial plant tolerance to herbivory. Trends in Ecology

$560 \quad$ and Evolution 9:145-148

561 Schowalter TD, Lowman MD (1999) Forest herbivory: insects. In Walker LR (ed) Ecosystems

562 of disturbed ground. Elsevier, Amsterdam. 253-269

563 Scott IM, Thaler JS, Scott JG (2010) Response of a Generalist Herbivore Trichoplusia ni to

564 Jasmonate-Mediated Induced Defense in Tomato. Journal of Chemical Ecology 36: 490-499

565 Shipley B (2000) Causes and correlations in biology: a user’s guide to path analysis, structural

566 equations and causal inferences. Cambridge University Press

567 Strauss SY, Agrawal AA (1999) The ecology and evolution of plant tolerance to herbivory.

$568 \quad$ Trends in Ecology and Evolution 14:179-185

569 Torchin ME, Mitchell CE (2004) Parasites, pathogens, and invasions by plants and animals.

$570 \quad$ Frontiers in Ecology and Environment 2:183-190

571 Torres JA (1992) Lepidoptera outbreaks in response to successional changes after the passage of

572 Hurricane Hugo in Puerto Rico. Journal of Tropical Ecology 8:258-298

573 Visser JH (1986) Host odor perception in phytophagous insects. Annual Review of Entomology

$574 \quad 31: 121-144$

575 Yates CN, Murphy SD (2008) Observations of herbivore attack on garlic mustard (Alliaria

576 petiolata) in southwestern Ontario, Canada. Biological Invasions 10:757-760 
578 Table 1 Results of path analysis of biotic and abiotic effects on rosette survival and adult seed

579 production of A. petiolata. Shown are decomposition of factor level total effects into direct and 580 indirect components; statistically significant $(\alpha=0.05)$ effects are shown in boldface.

\begin{tabular}{|c|c|c|c|c|c|}
\hline Habitat & $\begin{array}{l}\text { Life } \\
\text { stage }\end{array}$ & Definition of effect & Direct & Indirect & Total effect \\
\hline \multirow{18}{*}{$\begin{array}{l}\text { Forest } \\
\text { understory }\end{array}$} & \multirow{9}{*}{ Rosette } & Light $\rightarrow$ density & -0.016 & - & -0.016 \\
\hline & & Light $\rightarrow$ herbivory & -0.099 & +0.001 & -0.098 \\
\hline & & Light $\rightarrow$ survival & +0.030 & +0.009 & +0.039 \\
\hline & & Moisture $\rightarrow$ density & -0.020 & - & -0.020 \\
\hline & & Moisture $\rightarrow$ herbivory & -0.099 & +0.001 & -0.098 \\
\hline & & Moisture $\rightarrow$ survival & +0.126 & +0.008 & +0.134 \\
\hline & & Density $\rightarrow$ herbivory & -0.071 & - & -0.071 \\
\hline & & Density $\rightarrow$ survival & -0.174 & +0.001 & -0.173 \\
\hline & & Herbivory $\rightarrow$ survival & -0.063 & - & -0.063 \\
\hline & \multirow{9}{*}{ Adult } & Light $\rightarrow$ density & -0.113 & - & -0.113 \\
\hline & & Light $\rightarrow$ herbivory & -0.056 & +0.017 & -0.039 \\
\hline & & Light $\rightarrow$ seed production & +0.031 & -0.032 & -0.001 \\
\hline & & Moisture $\rightarrow$ density & -0.264 & - & -0.264 \\
\hline & & Moisture $\rightarrow$ herbivory & -0.066 & +0.040 & -0.026 \\
\hline & & Moisture $\rightarrow$ seed production & +0.217 & +0.016 & +0.233 \\
\hline & & Density $\rightarrow$ herbivory & -0.153 & - & -0.153 \\
\hline & & Density $\rightarrow$ seed production & +0.096 & -0.042 & +0.054 \\
\hline & & Herbivory $\rightarrow$ seed production & +0.373 & - & +0.373 \\
\hline & & Light $\rightarrow$ density & +0.078 & - & +0.078 \\
\hline
\end{tabular}




\begin{tabular}{|c|c|c|c|c|c|}
\hline Habitat & $\begin{array}{l}\text { Life } \\
\text { stage }\end{array}$ & Definition of effect & Direct & Indirect & Total effect \\
\hline \multirow{17}{*}{ Grasslands } & \multirow{8}{*}{ Rosette } & Light $\rightarrow$ herbivory & +0.094 & +0.013 & +0.107 \\
\hline & & Light $\rightarrow$ survival & +0.278 & -0.008 & +0.270 \\
\hline & & Moisture $\rightarrow$ density & -0.048 & - & -0.048 \\
\hline & & Moisture $\rightarrow$ herbivory & +0.338 & -0.008 & +0.330 \\
\hline & & Moisture $\rightarrow$ survival & +0.353 & -0.016 & +0.337 \\
\hline & & Density $\rightarrow$ herbivory & +0.163 & - & +0.163 \\
\hline & & Density $\rightarrow$ survival & -0.069 & -0.002 & -0.071 \\
\hline & & Herbivory $\rightarrow$ survival & -0.024 & - & -0.024 \\
\hline & \multirow{9}{*}{ Adult } & Light $\rightarrow$ density & -0.032 & - & -0.032 \\
\hline & & Light $\rightarrow$ herbivory & -0.092 & -0.008 & -0.100 \\
\hline & & Light $\rightarrow$ seed production & -0.054 & -0.038 & -0.092 \\
\hline & & Moisture $\rightarrow$ density & -0.008 & - & -0.008 \\
\hline & & Moisture $\rightarrow$ herbivory & +0.061 & -0.002 & +0.059 \\
\hline & & Moisture $\rightarrow$ seed production & +0.145 & +0.016 & +0.161 \\
\hline & & Density $\rightarrow$ herbivory & +0.255 & - & +0.255 \\
\hline & & Density $\rightarrow$ seed production & +0.325 & $+\mathbf{0 . 0 1 0}$ & +0.335 \\
\hline & & Herbivory $\rightarrow$ seed production & +0.302 & - & +0.302 \\
\hline
\end{tabular}


583 Table 2 Results of a fixed-effects factorial ANOVA of data from a palatability experiment in

584 which leaves of A. petiolata were exposed to larvae of Trichoplusia ni in petri dishes. Analyses

585 indicate whether palatability (per unit weight loss) varied with herbivory treatment (larva

586 addition vs. control), plant life stage, and habitat type.

\begin{tabular}{|c|c|c|c|c|}
\hline & $\begin{array}{l}\text { Sum of Squares } \\
\text { (Type III) }\end{array}$ & $\mathrm{df}$ & $\mathrm{F}$ value & $\operatorname{Pr}(>F)$ \\
\hline Herbivory treatment & 0.0067 & 1 & 9.10 & 0.003 \\
\hline Plant life stage & 0.0253 & 1 & 34.31 & $<0.001$ \\
\hline Habitat type & 0.0444 & 1 & 60.20 & $<0.001$ \\
\hline Herbivory treatment $\mathrm{x}$ Plant life stage & 0.0093 & 1 & 12.72 & $<0.001$ \\
\hline Herbivory treatment $x$ Habitat type & 0.0008 & 1 & 1.11 & 0.295 \\
\hline Plant life stage $\mathrm{x}$ Habitat type & 0.0175 & 1 & 23.79 & $<0.001$ \\
\hline Herbivory treatment $\mathrm{x}$ Plant life stage $\mathrm{x}$ & 0.0011 & 1 & 1.53 & 0.219 \\
\hline \multicolumn{5}{|l|}{ Habitat type } \\
\hline Error & 0.0531 & 72 & & \\
\hline
\end{tabular}




\section{$591 \quad$ List of Figures}

592 Fig. 1 Schematic diagram of hypothesized causal relationships among biotic and abiotic factors

593 that may govern the incidence of herbivory and factors that may modulate plant demography

594 (juvenile survival and adult seed production). It is anticipated that (i) incidence of herbivory may

595 be affected by environmental conditions (light and soil moisture) and conspecific (host) plant

596 density, where conspecific plant density itself may be affected by environmental conditions, and

597 that (ii) plant demographic traits may be affected by incidence of herbivory, conspecific plant

598 density and environmental conditions. The direction of direct effects, as indicated with arrows

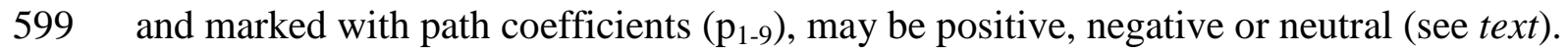

600 Fig. 2 Interaction plot showing the dependency of incidence of herbivory (logit scale) on plant

601 life stages in forest understory and grasslands.

602 Fig. 3 Results of spatial path analysis showing direct relationships among variables. Only

603 significant relationships ( $\alpha=0.05$ ) are shown (see Table 1 for complete table of direct and

604 indirect effects including statistically non-significant trends). Solid lines indicate positive effects

605 and dotted lines indicate negative effects, $\varepsilon$ indicates independent errors associated with each

606 relationship and $\lambda$ indicates the coefficient of the spatial error term. Standardized path

607 coefficients (direct effects; $\mathrm{p}_{1}-\mathrm{p}_{9}$ ) are presented alongside each line. Different sample sizes $(N)$

608 were due to variation in abundance of rosette or adults.

609 Fig. 4 Representative images showing a selection of the herbivore treated leaves at the end of the

610 palatability experiment. Leaves were exposed to larvae of Trichoplusia ni in petri dishes. 
Biswas et al.: Herbivory in A. petiolata

612 Fig. 5 Interval plots (mean \pm 95\% confidence interval) showing the dependence of leaf

613 palatability (higher weight loss per unit biomass means higher palatability) of A. petiolata on

614 plant life stage (rosette vs. adult) and habitat 
615

616

617

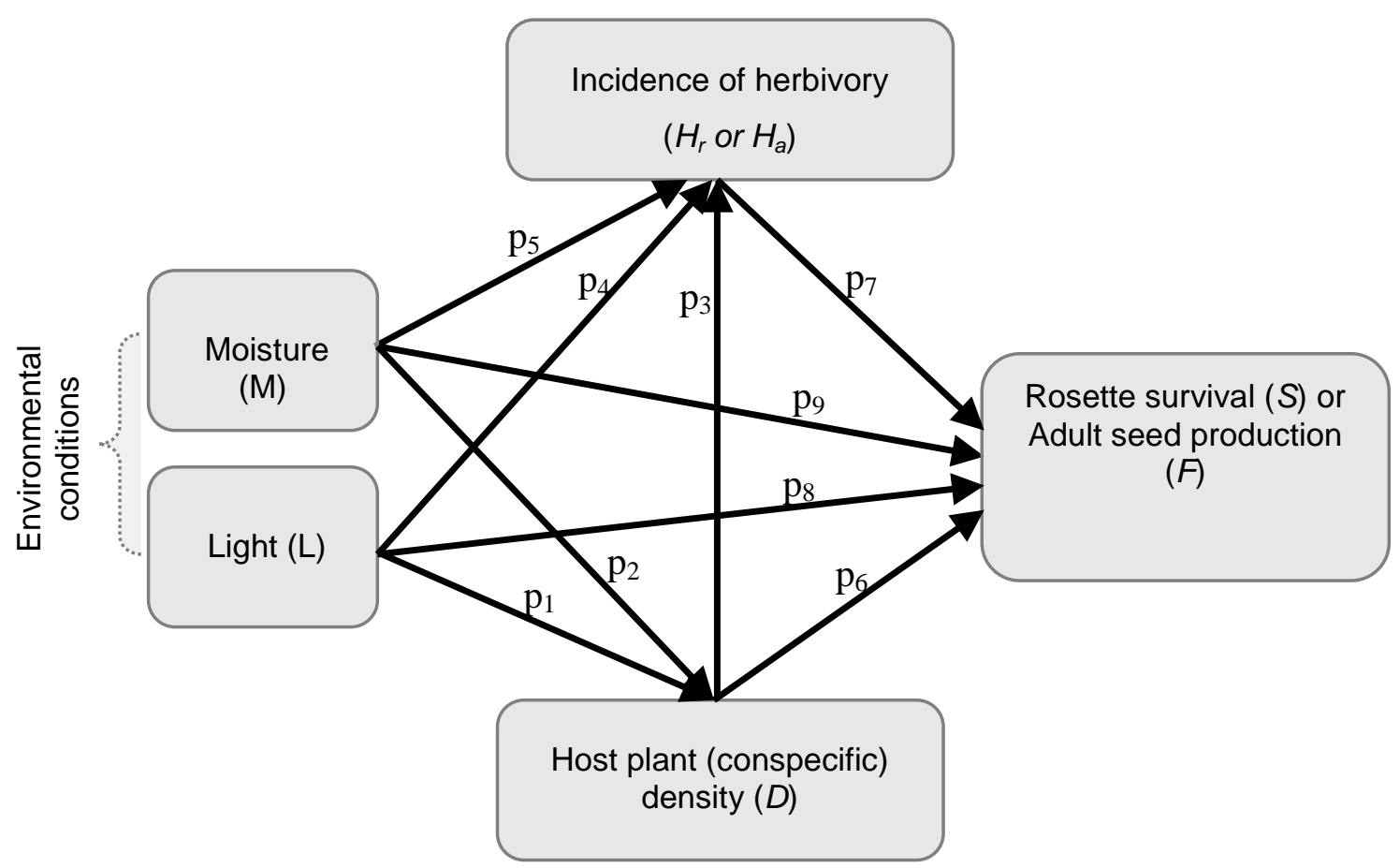

Fig. 1 


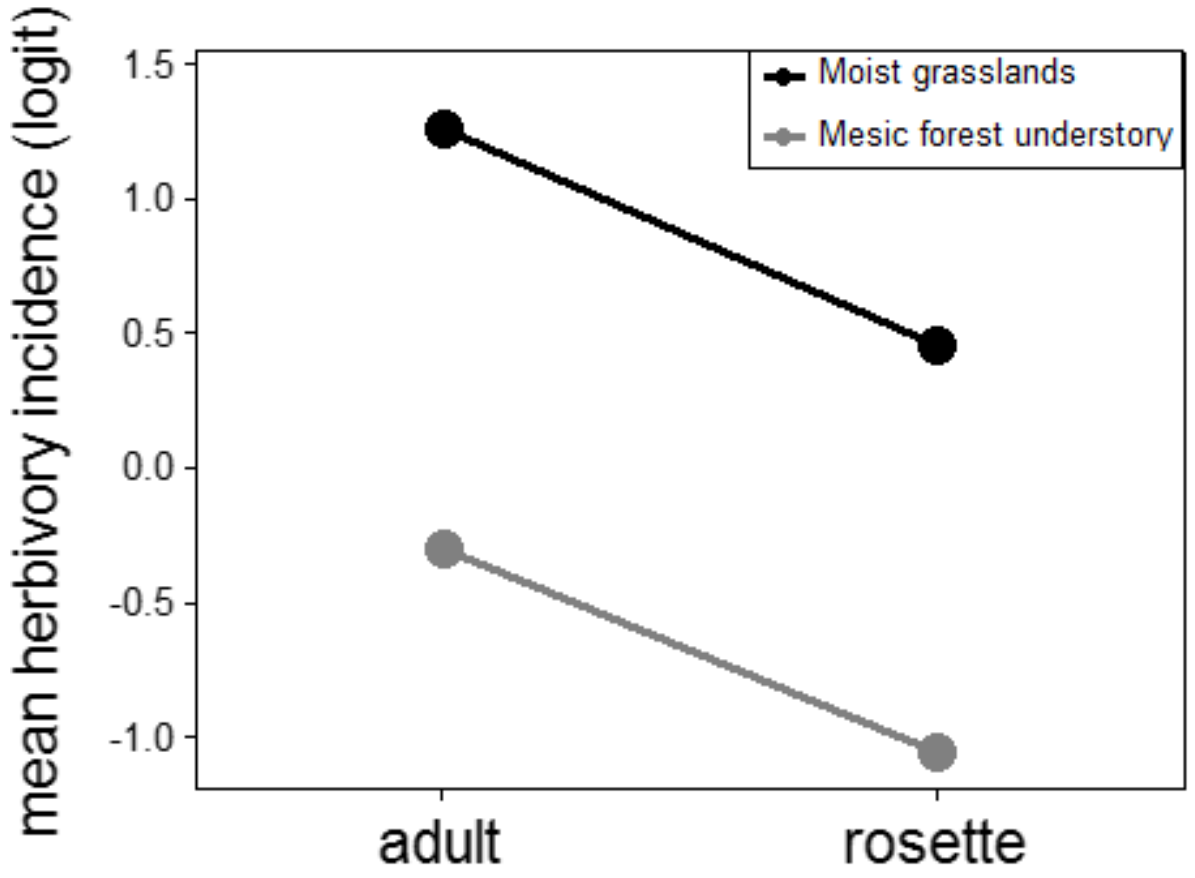




\section{Rosette}

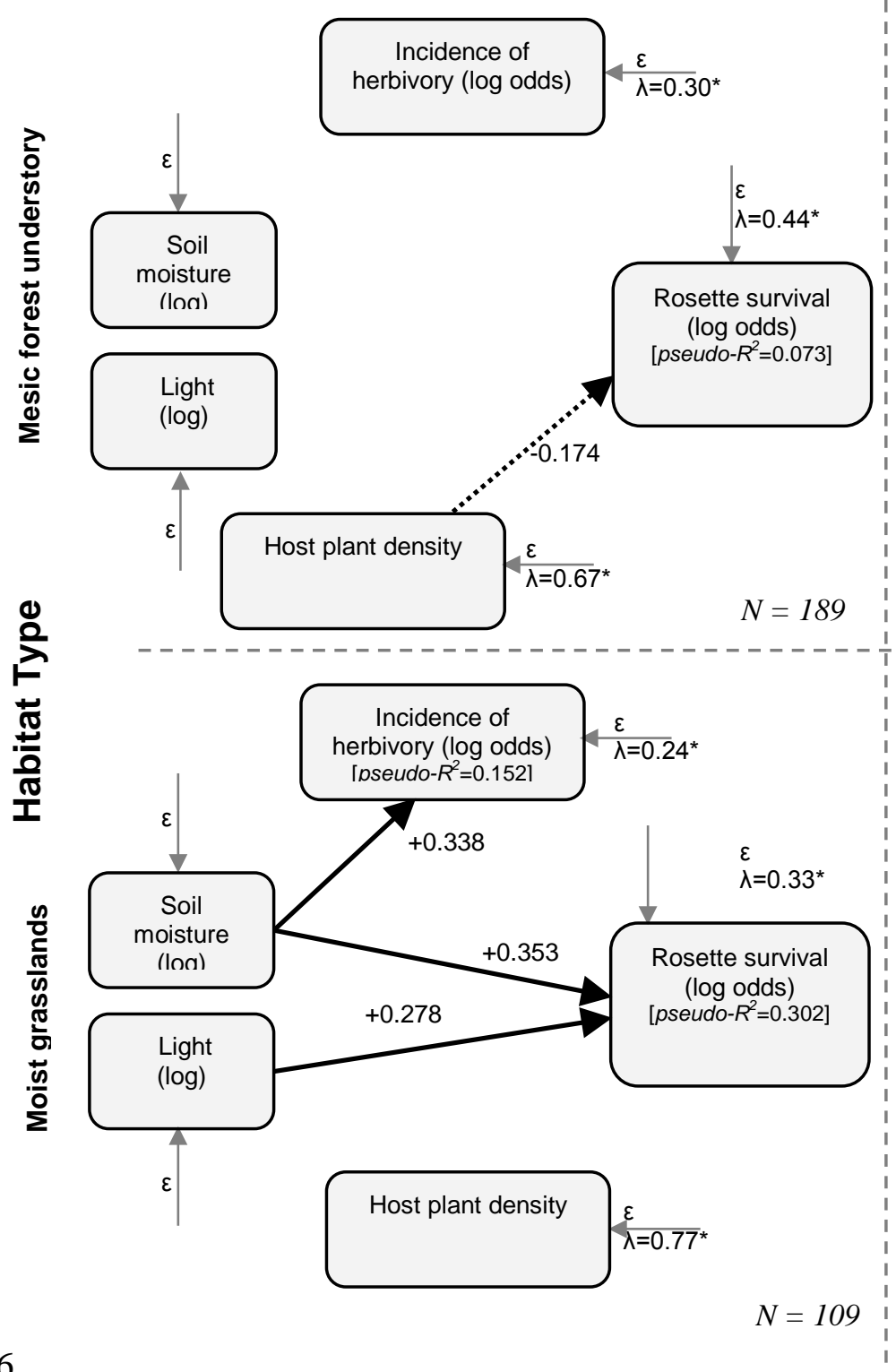

Adult

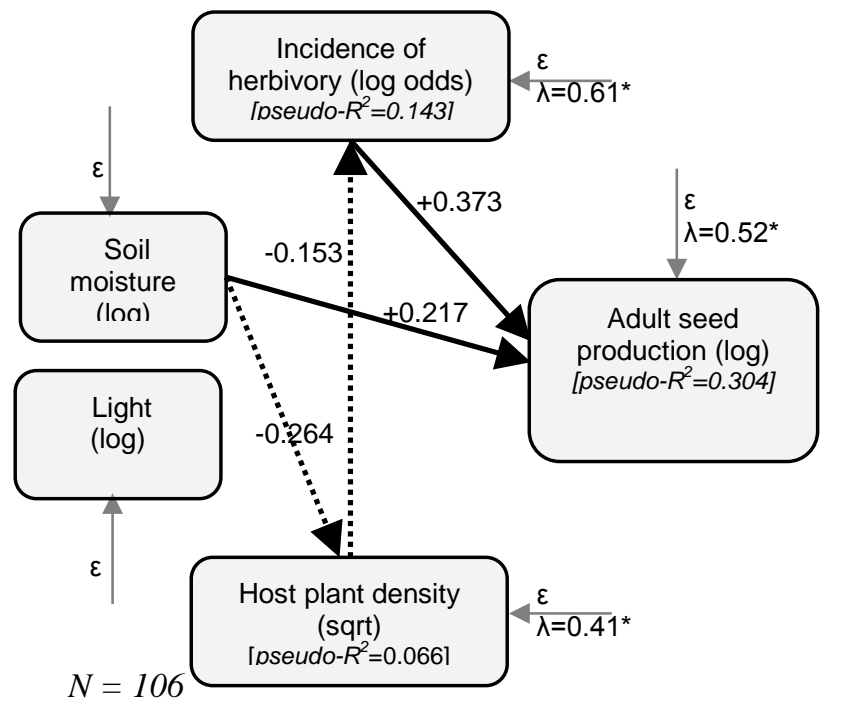

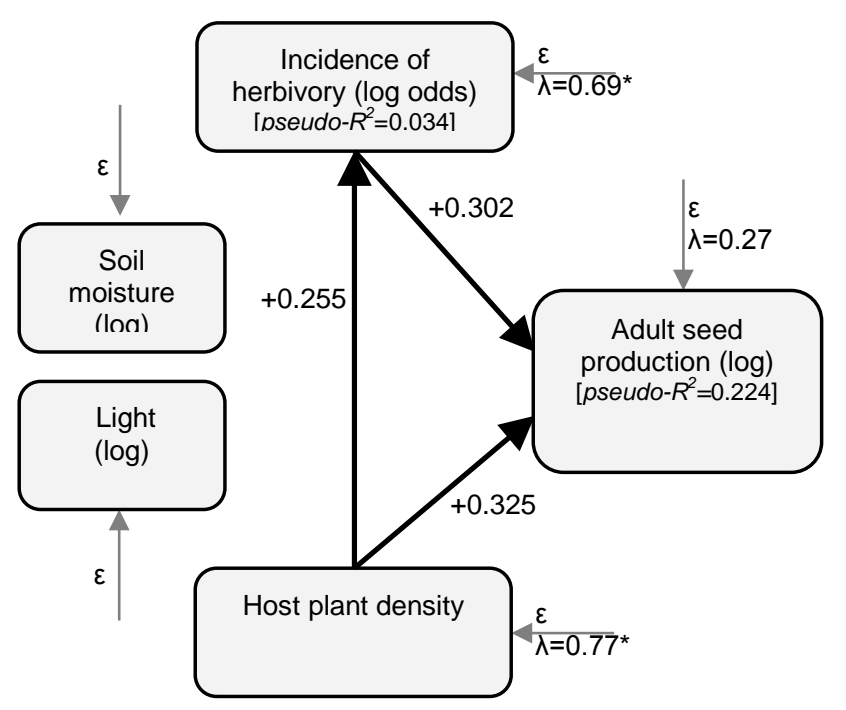

$N=36$ 


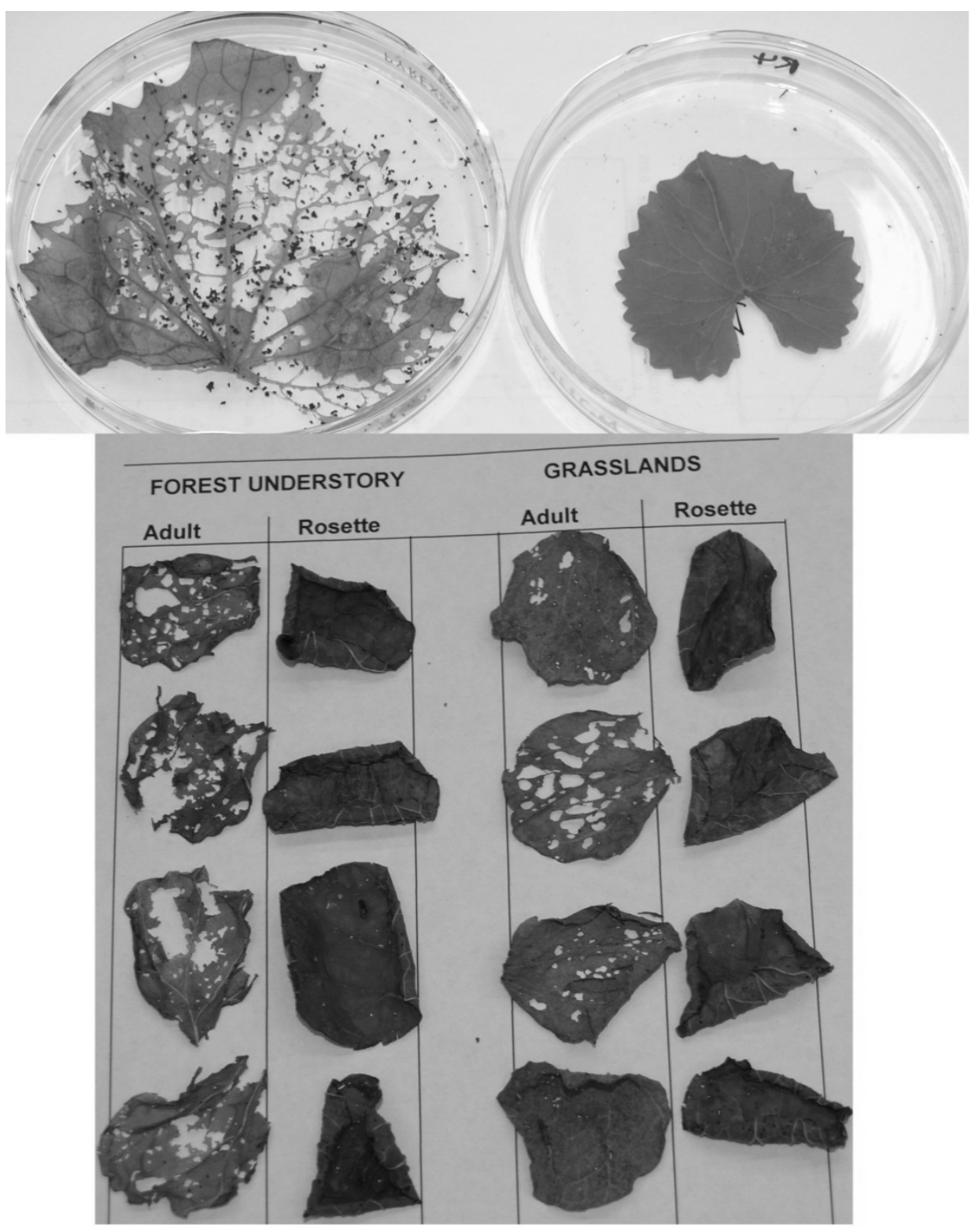

630

Fig. 4

631

632 


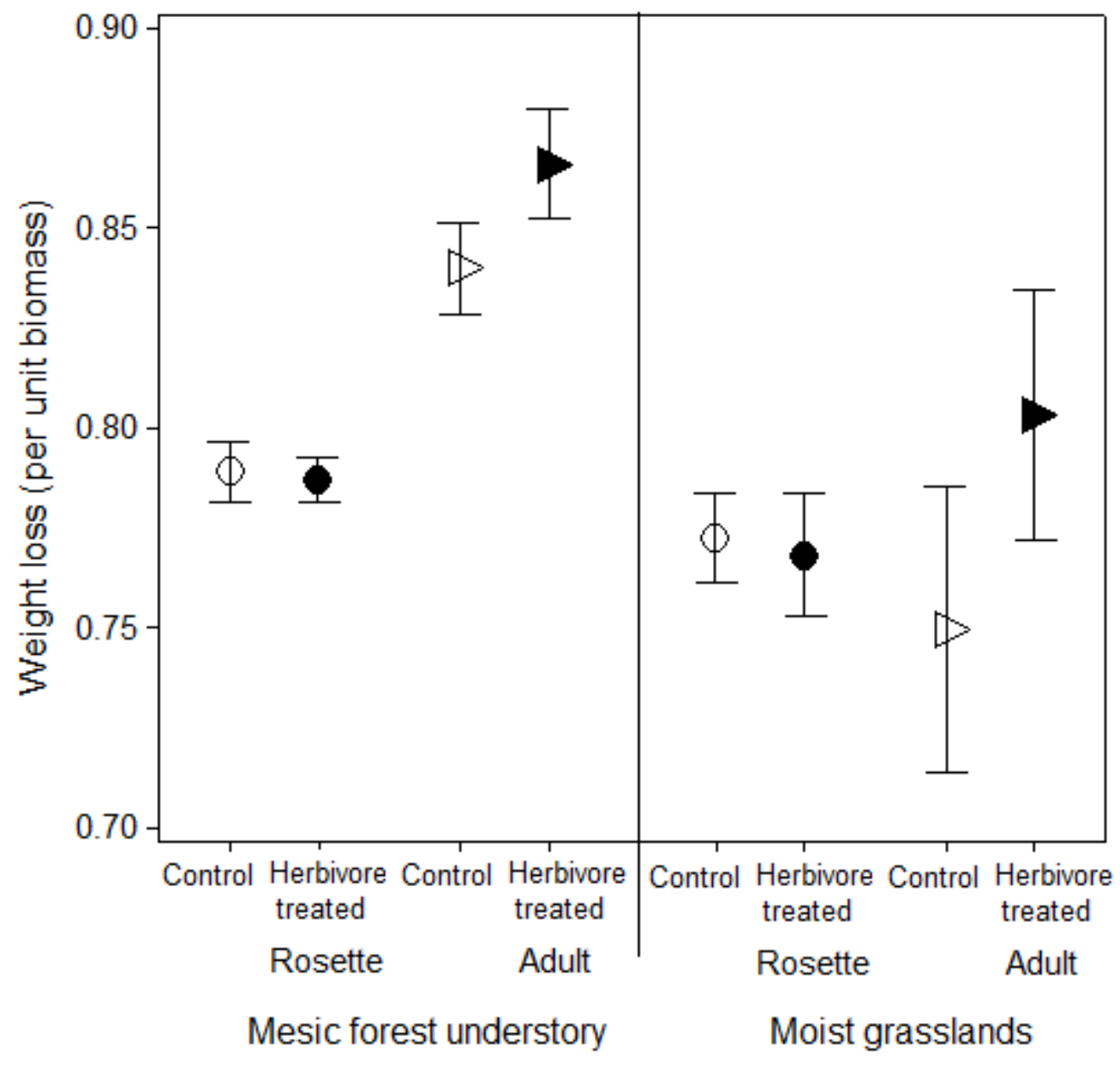

634

Fig. 5

635 